Historia Slavorum Occidentis

2021, nr 1 (28)

ISSN 2084-1213

DOI: $10.15804 /$ hso210103

EdUARd MÜhle (MÜNSTER)

\title{
Czym były elity społeczne wczesnego średniowiecza? Próba zdefiniowania świeckiego możnowładztwa polskiego pierwszej połowy XII w.
}

Słowa kluczowe: historia średniowieczna, Polska, możnowładztwo, kultura

Keywords: medieval history, Poland, nobility, culture

Abstract: The article explores how the comes Piotr Włostowic fits into a set of criteria (such as distinguished descent; a considerable material wealth; participation in royal/ducal power; a disposition over Church offices and/or a special dedication to Church matters) defining high medieval Polish nobility.

Pytania o to, czym były elity społeczne wczesnego średniowiecza, lub też o genezę szlachty stanowią jedne z najdawniejszych i najważniejszych pytań polskiej mediewistyki. Odpowiedź jest powszechnie znana: szlachta odgrywała w Polsce aż do XX w., zarówno pod względem jakościowym, jak i ilościowym, niezwykle istotną rolę ${ }^{1}$ Jednak tak samo jak dawna i wielokrotnie dyskutowana jest kwestia średniowiecznych początków tej - w kontekście europejskim - wyjątkowo silnie dominującej warstwy społecznej, tak też w równym stopniu trudno jest na to pytanie odpowiedzieć jedno-

1 F. Maksay, Les Pays de la noblesse membreux, [w: Études historiques, éd. Z.P. Pach, Budapest 1980, s. 167-191 już w tytule swego artykułu trafnie to sformułował. 
znacznie. Aż do dziś nauka dostarcza zróżnicowanych, częściowo nawet przeciwstawnych interpretacji genezy polskiej szlachty ${ }^{2}$. Odmienne punkty widzenia wynikają też stąd, że istnieje wiele odpowiedzi na pytanie, czym właściwie była średniowieczna szlachta lub co mediewistyka powinna mianem „szlachty” określać. Najpierw musimy więc porozmawiać o problemach definicyjnych. A priori możemy pominąć przy tym takie pojęcie szlachty, które ujmuje ją jako prawnie określony, dziedziczny stan - takiego w Polsce aż do końca XIV-XV w. w ogóle nie było. Skoro jednak w wypadku wczesnego i pełnego średniowiecza odpada nam to 'proste', bo jednoznaczne, prawne kryterium definicyjne - zresztą nie tylko jeśli chodzi o Polskę - to, do jakich cech lub właściwości możemy się odwołać, jeśli chcemy pewną określoną część społeczeństwa także w tym wczesnym okresie nazwać mianem szlachty? Nowsze badania oczywiście już zgodnie twierdzą, że może tu chodzić tylko o opisanie pewnego „typu idealnego" w rozumieniu Maxa Webera - typu idealnego, który, jak w przypadku innych „typów idealnych”, jak np. średniowiecznego „miasta” („Stadt”), może najszybciej zostać uchwycony przy pomocy „wiązki kryteriów”, przy czym jest jasne, że poddawane badaniu „typy realne” niekoniecznie w każdym wypadku obejmą wszystkie kryteria „typu idealnego”. Zresztą co do wiązki kryteriów będącej podstawą typu idealnego „szlachty” nie ma jeszcze w nauce pełnej zgody. Jak ukazuje zestawienie dowolnie wybranych prób definiowania, da się jednak z powodzeniem ustalić punkt przecięcia zbiorów, który mógłby lec u podstaw naszych dalszych rozważań3 ${ }^{3}$ Jako członków średniowiecznej polskiej szlachty możemy wtedy traktować takie osoby, co do których można wykazać: 1 . wysokie pochodzenie w ramach rodu lub rodziny, 2 . znaczny stan materialnego posiadania w postaci dochodów z urzędów i/albo własności ziemskiej, 3. udział we władzy królewskiej lub książęcej i 4. posiadanie stanowisk kościelnych lub szczególne zaangażowanie na rzecz Kościoła.

2 Najważniejsze nowe opracowanie przedstawia T. Jurek, Geneza szlachty polskiej, [w: S Šlechta, moc a reprezentace ve středověku, red. M. Nodl, M. Wihoda, Praha 2007, s. 63-140.

3 Por. O.G. Oexle, Aspekte der Geschichte des Adels im Mittelalter und in der frühen Neuzeit, [w: ] Europäischer Adel 1750-1950, hrsg. v. H.U. Wehler, Göttingen 1990, s. 19-56, tu s. 21-25; W. Conze, Adel, Aristokratie, [w:] Geschichtliche Grundbegriffe, Bd. I, hrsg. v. O. Brunne, W. Conze, R. Koselleck, Stuttgart 1992, k. 1-48, tu k. 1; W. Paravicini, Interesse am Adel. Eine Einleitung, [w: ] Nobilitas. Funktion und Repräsentation des Adels in Alteuropa, hrsg. v. W. Paravicini, O.G. Oexle, Göttingen 1997, s. 9-25, tu s. 15-17; W. Hechberger, Adel, Ministerialität und Rittertum im Mittelalter, München 2004, s. 2-4; T. Jurek, Vom Rittertum zum Adel. Zur Herausbildung des Adelsstandes im mittelalterlichen Schlesien, [w:] Adel in Schlesien, Bd. I, Herrschaft - Kultur Selbstdarstellung, hrsg. v. J. Harasimowicz, M. Weber, München 2010, s. 53-76, tu s. 54-55. 
W związku ze stosunkowo słabą bazą źródłową dla polskiego wczesnego i pełnego średniowiecza nie jest jednak łatwo uściślić tę wiązkę kryteriów na podstawie odniesienia do konkretnych osób czy jednostek i/lub grup osób czy zbiorowości. Dostępne źródła z X-XII w. nie dają prawie żadnego lub mało wiarygodny wgląd w prozopografię, genealogię i historię rodów. Dopiero od XIII w., w miarę zagęszczania się przekazów, źródła zaczynają być pod tym względem bogatsze. Co możemy więc - jeśli nie chcemy zdać się wyłącznie na raczej abstrakcyjne i niepewne wnioski tak zwanej metody retrogresywnej czy pewne wskazówki archeologii - powiedzieć na temat genezy i rozwoju polskiej szlachty przed końcem XII w.? Na szczęście przynajmniej w wypadku jednej dwunastowiecznej postaci dostępny materiał źródłowy stwarza możliwość zweryfikowania ustalonej wiązki kryteriów, a co za tym idzie, typu idealnego „szlachty” z rzeczywistością historyczną - na tyle, na ile możemy ją poznać czy rekonstruować. Chodzi przy tym o postać, która w siedmiu dwunastowiecznych źródłach, w jakich jest wspomniana, nazywana jest comes Petrus, raz też comes palatinus Petrus. Zmarł on w 1153 r. i w polskiej nauce znany jest jako Piotr Włostowic, w niemieckiej jako Peter Wlast i od dawna zajmuje uwagę uczonych ${ }^{4}$. Co w odniesieniu do naszych czterech wyznaczników szlachty (1. pochodzenie rodzinne, 2. stan posiadania, 3. udział we władzy i 4. rola w życiu kościelnym) można wywnioskować ze źródeł na temat owego Petrusa i jak mają się odpowiednie informacje do odnośnej naukowej dyskusji? Omówmy każdy z tych czterech wyznaczników z osobna.

4 Por. A. Mosbach, Piotr, syn Wtodzimirza, sławny dostojnik Polski wieku dwunastego i kronika opowiadająca dzieje Piotrowe, Ostrów 1865; C. Grünhagen, Die Vertreibung Władysławs II. von Polen und die Blendung Peter Wlasts, Zeitschrift des Vereins für Geschichte Schlesiens 12 (1874), s. 77-97; F. von Heydebrand und der Lasa, Peter Wlast und die nordgermanischen Beziehungen der Slaven, Zeitschrift des Vereins für Geschichte Schlesiens 61 (1927), s. 247-278; H. Uhtenwoldt, Peter Wlast, der Siling und Breslau, Beiträge zur Geschichte der Stadt Breslau 2 (1936), s. 32-102; M. Plezia, Palatyn Piotr Włostowicz. Sylwetka z dziejów Śląska w XII wieku, Warszawa 1947; E. Richtsteig, Peter Wlast, Archiv für schlesische Kirchengeschichte 18 (1960), s. 1-27; 19 (1961), s. 1-24; 20 (1962), s. 1-28; S. Bieniek, Piotr Wtostowic. Postać z dziejów średniowiecznego Śląska, Wrocław 1965; S. Trawkowski, Piotr Włostowic, [w: ] Polski Stownik Biograficzny, t. 26, red. E. Rostworowski, Wrocław 1980, s. 355-358; H. Łowmiański, Początki Polski. Polityczne i społeczne procesy ksztattowania się narodu do początku wieku XIV, t. 6, cz. 1, Warszawa 1985, s. 268-286; J. Bieniak, Polska elita polityczna XII wieku, Część III A. (Arbitrzy książąt - krąg rodzinny Piotra Włostowica), [w:] Społeczeństwo Polski średniowiecznej, t. 4, red. S.K. Kuczyński, Warszawa 1990, s. 13-107. 


\section{O pochodzeniu komesa Piotra}

Datowane na 1143/1145 i 1201 r., jednak wszystkie bez wyjątku przekazane w późniejszych odpisach dokumenty, w których zaistniał comes Petrus, ukazują go jako vir nobilis, występującego we Wrocławiu i jego najbliższej okolicy wraz z innymi członkami jego rodu czy rodziny - z cognatus Ceseborius i z frater Boguslaus - jako fundator dóbr kościelnych ${ }^{5}$. Jako obszar życia i działania komesa Piotra rozpoznajemy tu środkowy Śląsk. W tym regionie miał on dostęp do własności ziemskiej oraz regaliów - tawerny, targu, przeprawy na Odrze. Źródła milczą na temat tego, w jaki sposób znalazły się one w jego posiadaniu. Tylko z jednego źródła, mianowicie bulli papieża Celestyna III z 9 IV 1193 r., w której potwierdzone zostały posiadłości i prawa wroclawskiego opactwa na Piasku - do którego jeszcze wrócę - dowiadujemy się, że posiadłości, które Piotr przekazał niegdyś klasztorowi, należały do niego zgodnie z prawem dziedziczenia po ojcu i dziadku (ex parte avi et patris sui iure hereditario contingebant) ${ }^{6}$. Jeśli damy wiarę tej wskazówce, znaczyłoby to, że rodzina komesa Piotra w czasie donacji zamieszkiwała we Wrocławiu i jego okolicach już w trzecim pokoleniu.

Jednak powstałe mniej więcej w tym samym czasie źródła narracyjne - kontynuowana jeszcze za życia komesa Piotra w klasztorze Zwiefalten kronika mnicha Ortlieba $^{7}$, Annales Magdeburgenses ${ }^{8}$ i powstały w 1159 r., a więc sześć lat po śmierci Piotra, żywot św. Ottona z Bambergu pióra mnicha Herborda ${ }^{9}$ - nie zawężają pola działania Piotra do Śląska ani nie mówią o posiadłościach ziemskich, które miałby tam posiadać czy odziedziczyć po swych przodkach. Ukazują one Piotra raczej jako wybitnego wodza Polaków (ditisimus Boloniorum princeps; militiae ductor, praefectus super viros bellatores), który pozostawał w bliskich związkach z księciem i któ-

5 Schlesisches Urkundenbuch, Bd. I, hrsg. v. H. Appelt, Wien 1971 (dalej SUB), nr 11 (1143-1145), nr 19 (1139-1149), nr 23 (1149-1150), nr 58 (1180-1201), nr 59 (1193), nr 60 (1193) i nr 61 (1193), w oryginale zachowały się obydwie bulle papieża Celestyna nr 59 i 60.

6 SUB nr 61.

7 Ortliebi de fundatione monasterii zwivildensis, libri II, ed. O. Abel, [w: ] MGH SS, t. X, ed. G.H. Pertz, Hannover 1852, s. 64-92, tu s. 90-92.

8 Annales Magdeburgenses, [w: ] MGH SS, t. XVI, ed. G.H. Pertz, Hannover 1859, s. 105-196, tu s. 187.

9 Vitae Ottonis episcopi Bambergensis. Vita auctore Herbordo, et anonymi vita Ottonis ex Herbordi dialogo confecta, ed. R. Köpke, [w:] MGH SS, t. XII, ed. G.H. Pertz, Hannover 1856, s. 746-822, tu s. 776-777. 
ry w jego imieniu - jak twierdzi Herbord i kontynuator Ortlieba - lub w ramach własnego władztwa (principatus) - jak chcą Roczniki Magdeburskie - aktywnie i z powodzeniem działał na polu polityki. Brak tu wskazówek odnośnie do jego pochodzenia i więzi rodzinnych. Również w powstałej cztery dekady po śmierci Piotra Kronice Polskiej (Chronica Polonorum) mistrza Wincentego, u którego opis Piotra jako energicznego książęcego wodza następuje po cytowanych współczesnych opowieściach, nie ma mowy o regionalnych posiadłościach ani o określonym regionalnym pochodzeniu ${ }^{10}$. O rodzinie Piotra Wincenty wspomina co najwyżej wtedy, gdy mówi o jego wysokim pochodzeniu (alti sanguinis). Nie wynika ono jednak w pierwszej linii ze strony jego rodziców, ale najpewniej z racji jego ożenku z córką ruskiego księcia lub małżeństwa jego własnej córki z księciem Słowian Połabskich, Jaxą z Kopanika. O rodzicach Wincenty wspomina w każdym razie wtedy, gdy wymienia patronim Vlostides, czym wskazuje najwyraźniej na ojca Piotra - człowieka o imieniu Vlast. To samo sformułowanie zawiera prawie dosłownie Kronika Wielkopolska ${ }^{11}$. Ten powstały prawdopodobnie pod koniec XIII w., ale może też dopiero w latach 1370-1380 tekst zawiera pewien dodatek do imienia Piotr i nazywa go Petrus Wlostides de Kszansz. Jako że badacze przyjmują, iż wielkopolski kronikarz mógł poza kroniką mistrza Wincentego czerpać także z zaginionej kopii Wincentego, ta wskazówka co do pochodzenia nie musi być jedynie wymysłem późniejszego kronikarza. Mówi ona - rozumiana historycznie i interpretowana jako polska miejscowość Książ - nie o Śląsku, ale albo o Małopolsce, albo o Kujawach jako miejscu, z którego pochodził Petrus Vlostides. Kronika Wielkopolska nie poprzestaje jednak na tym nowym pochodzeniu Piotra, ale przeprowadza pewne dziwne rozszczepienie jego osoby na najwyraźniej dwóch różnych Piotrów. W jednym fragmencie donosi ona mianowicie najpierw o jednym Piotrze, który jako wytworny młodzieniec przybył z Królestwa Danii (nobilis adolescens de regno Dacie) do Polski, na służbę do Bolesława Krzywoustego, którego namówił do wyprawy przeciw Królestwu Danii, w trakcie której uprowadził do Polski skarb królewski (thezaurum regium), przy którego pomocy z kolei zyskał następnie wiele posiadłości (multas possesiones) i potem ożenił się z córką ruskiego księcia, będącą równocześnie krewną Bolesława Krzywoustego. W kolejnym urywku kronika przedstawia następnego Piotra, właśnie tego Petrus Wlostides de Kszansz, który jako wierny drużynnik Bolesława Krzywoustego

10 Magistri Vincentii dicti Kadłubek Chronica Polonorum, wyd. M. Plezia, MPH s.n., t. XI, Kraków 1994, s. 107-110.

11 Chronica Poloniae Maioris, wyd. B. Kürbis, MPH s.n., t. VIII, Warszawa 1970 (dalej Kürbis 1970), s. 38-41, 49-50. 
podstępnie i podle uprowadza ruskiego księcia Wołodara - o czym w tej formie donosili już kontynuator Ortlieba, ale także Herbord i Wincenty, przy czym dwaj ostatni wskazali dodatkowo na olbrzymią kwotę okupu, jaką razem z księciem Bolesławem za uwolnienie porwanego miał wymusić Piotr. Ten okup zamienił się chyba w Kronice Wielkopolskiej w ów thezaurus regium, skarb królewski, który ten drugi Piotr miał przywieźć do Polski z Danii. Widzimy, że mamy do czynienia ze znacznym przekręceniem starszego przekazu, z pomieszaniem informacji, do których najwyraźniej wkradły się też podane w innym miejscu wiadomości o pewnym innym, historycznym, żyjącym w tym samym czasie Petrus Magnus filius Wszcheborii, mianowicie Piotrze Wszeborowicu, kujawskim palatynie i kasztelanie Kruszwicy ${ }^{12}$.

Choć Kronika Wielkopolska odeszła całkiem mocno od oryginalnego przekazu dotyczącego naszego komesa Piotra, to jej narracja o „Piotrze Duńczyku” stała się punktem wyjścia do silnie oddziałującej alternatywnej interpretacji pochodzenia komesa Piotra. Ta pasowała równie dobrze do wczesnonowożytnej mody panującej wśród polskiej szlachty na poszukiwanie własnych korzeni poza Polską, jak i do tak zwanej „teorii podboju” lub „teorii normańskiej”, znajdującej w XIX i XX w. licznych przedstawicieli wśród polskich i niemieckich historyków. Zgodnie z tą teorią, wspartą też pewnymi archeologicznymi i językoznawczymi argumentami, których nie mogę tu szeroko i krytycznie omówić, nie tylko comes Petrus, lecz także spora część polskiej szlachty miałaby pochodzić od napływowych obcych, i to takich, którzy mieli przybyć do Polski przede wszystkim ze Skandynawii, częściowo jednak także jako normańscy drużynnicy - z Rusi Kijowskiej. Polska nauka widziała przy tym komesa Piotra na ogół nie tyle jako skandynawskiego przybysza, ile zazwyczaj - tak na przykład według Mariana Friedberga w 1925 r. - opisywała jedynie jego przodków jako przybyłych w X-XI w. Duńczyków ${ }^{13}$. Inni historycy - jak Henryk Łowmiański i Teresa Kiersnowska - chcieli widzieć jego przodków w ruskich Waregach, którzy albo zostali w 1018 r. sprowadzeni do Polski przez Bolesława Chrobrego z jego wyprawy kijowskiej, albo w połowie XI w. zostali przez Jarosława Mądrego oddani do dyspozycji Kazimierzowi Odnowicielowi w celu wsparcia stłumienia rebelii mazowieckiego Masława/Miecława i odbudowy piastowskiej władzy, a następnie osiedlili się na Mazowszu ${ }^{14}$. Marek Cetwiński próbował udowodnić bezpośrednie ruskie

12 Tak Brygida Kürbis w swoim komentarzu Chronica Poloniae Maioris - Kürbis 1970, s. 150, przyp. 215 i s. 151 , przyp. 224.

13 Tak M. Friedberg, Ród Łabędziów w wiekach średnich, Rocznik Towarzystwa Heraldycznego 7 (1924/1925), s. 1-100, tu s. 16.

14 Tak na przykład H. Łowmiański, Początki Polski. Z dziejów Słowian w I tysiącleciu n.e., t. 4, 
pochodzenie komesa Piotra, czyniąc z niego syna pewnego Svjatislava Davidoviča, który od 1106 r. był mnichem w czarnogórskim klasztorze. Jako jego młodszy syn Piotr miał w 1103 r. przybyć do Polski w orszaku Zbysławy, córki kijowskiego księcia Świętopełka i pierwszej żony Bolesława Krzywoustego ${ }^{15}$.

Niemieccy historycy i badacze Europy Wschodniej („Ostforscher”) oczywiście szczególnie chętnie podchwycili wskazówkę Kroniki Wielkopolskiej i wyprowadzoną z niej - m.in. także u Jana Długosza - tradycję nordyckiego pochodzenia Piotra w kontekście swych teorii nośników kultury i teorii germańskich. Chcieli w Piotrze Włoście widzieć „Wikinga na wschodnioniemieckiej ziemi” i zaznaczali, że jego postać - tak stwierdził w 1940 r. Hermann Uhtenwoldt - „tylko wtedy staje się zrozumiała, gdy postrzegamy go i oceniamy jako Germanina z Północy" ${ }^{16}$. Takie teorie z lekkimi modyfikacjami były jeszcze w latach sześćdziesiątych obecne w zachodnioniemieckim czasopiśmie naukowym, co przemawia raczej nie za ich słusznością, ale za odpornością antysłowiańskiej arogancji w niemieckich badaniach nad Europą Wschodnią („Ostforschung”).

Polska nauka po 1945 r. - w nawiązaniu do starszych wyobrażeń, jak np. teoria rodowa Władysława Semkowicza ${ }^{17}$ - wypracowała wyraźne, równie jednostronne stanowisko. Także ono było nacechowane bieżącymi polityczno-historycznymi interesami, miało bowiem wykazać prapolski charakter Śląska jako części „ziem odzyskanych" po 1945 r. Comes Petrus był tu więc potomkiem rdzennego śląskiego rodu ${ }^{18}$. Ród ten - według Stanisława Bieńka w 1965 r. - wykształcił się w trakcie długiego procesu z masy wolnej i równej słowiańskiej ludności plemiennej, wśród której już w VII-IX w. uformowały się różnice w stanie posiadania. Zwierzchność nad tą ludnością plemienną miał mieć wódz wybrany przez wiec. Ci przywódcy w chwili piastowskiego podboju Śląska musieli wprawdzie zrezygnować ze swej niezależności,

Warszawa 1970, s. 185; t. 5, Warszawa 1973, s. 464 i n.; tenże, Zagadnienie roli Normanów w genezie państw słowiańskich, Warszawa 1957, s. 31 i n.; T. Kiersnowska, Jeszcze o Piotrze Wtostowicu i pochodzeniu rodu Łabędziów, [w: Społeczeństwo Polski średniowiecznej, t. 9, red. S.K. Kuczyński, Warszawa 2001, s. 55-64.

15 M. Cetwiński, Piotr Wtostowic czy Piotr Rusin?, Sobótka 29 (1974), s. 429-443, tu s. 441.

16 Tak na przykład H. Uhtenwoldt, Peter Wlast. Graf von Breslau. Ein Wikinger auf ostdeutschem Boden, Breslau 1940, s. 11.

17 W. Semkowicz, Uwagi metodyczno-krytyczne nad pochodzeniem i rozsiedleniem rycerstwa polskiego wieków średnich, Miesięcznik Heraldyczny 5 (1912), s. 41-47, 73-77; tenże, Ćwierćwiecze badań monograficznych nad rodami rycerstwa polskiego, Miesięcznik Heraldyczny 12 (1933), s. 177-183.

18 Por. M. Plezia, Palatyn Piotr, zwł. 15-16; S. Bieniek, Piotr Wtostowic, zwł. s. 6-9. 
mogli jednak zachować swe dawne bogactwa, przywileje i pozycję. W ten sposób dawni wodzowie plemienni - a wśród nich przodkowie komesa Piotra - przekształcili się w wiodących możnych wczesnopiastowskiego państwa i odtąd tworzyli zasadniczą część kształtującej się szlachty. Jako dowody na tę teorię w odniesieniu do komesa Piotra z przedstawionego materiału źródłowego przytacza się szczególnie wskazówkę bulli Celestyna III w sprawie odziedziczonych po ojcu i dziadku śląskich dóbr, m.in. na Ślęży, gdzie znajdowało się dawne pogańskie sanktuarium - do czego jeszcze powrócę. Poza tym wymienia się obecne u Herborda i Wincentego określenie princeps. Ten tytuł, poświadczony dla niektórych możnych piastowskich XI-XII w., jest - w odróżnieniu od tytułu comes - zarezerwowany dla dawnych wodzów plemiennych lub ich potomków.

Przedstawione teorie w sprawie pochodzenia komesa Piotra odzwierciedlają dwie zasadnicze, przeciwstawne, obecne w nauce odpowiedzi na pytania o średniowieczne korzenie i początki polskiej szlachty: 1. wyraźnie od XII-XIII w. widoczna szlachta sięga - jak w 1978 r. napisał Aleksander Gieysztor w Lexikon des Mittelalters - najwyższej, uprzywilejowanej dziedzicznie elity społecznej jeszcze z czasów plemiennych ${ }^{19} ; 2$. szlachta formowała się na bazie warstwy wojowników, którzy w kontekście kształtowania się władztwa piastowskiego byli napływowi lub zostali sprowadzeni przez piastowskich książąt. Zawieśmy na chwilę odpowiedź na pytanie, do którego punktu widzenia się przychylić albo czy istnieje jakieś trzecie rozwiązanie, i prześledźmy najpierw źródła pod kątem trzech kolejnych ustalonych na wstępie kryteriów ${ }^{20}$.

\section{W sprawie majątku komesa Piotra}

Czy komes Piotr posiadał wielkie dziedziczne dobra ziemskie lub jakiego rodzaju był jego majątek, który miał go wyróżniać z pozostałej ludności? Z bulli papieża Celestyna III wiemy już, że po ojcu i dziadku odziedziczył pewne posiadłości ${ }^{21}$. Jest to jednak jedyna bezpośrednia wskazówka na temat dóbr dziedzicznych komesa Piotra. Nie chcę jej w żadnym razie kwestionować - w przeciwieństwie do Marka

\footnotetext{
19 A. Gieysztor, Adel. F. Westslawen, [w:] Lexikon des Mittelalters, Bd. I, Zürich 1999, k. 137-138 [1978] i podobnie jeszcze A. Wędzki, Możni, [w:] Wczesna Stowiańszczyzna. Przewodnik po dziejach i literaturze przedmiotu, t. I, red. A. Wędzki, Warszawa 2008, s. 353.

20 Por. przyp. 14.

21 Por. przyp. 6.
} 
Cetwińskiego, który podważa autentyczność bulli² ${ }^{22}$ Ojciec Piotra o patronimikum Vlostides ma przecież konotacje słowiańskie, mógł więc albo być już urodzony w Polsce, albo zasymilowany tu szybko po swoim przybyciu, w każdym razie był w stanie pozyskać pewne posiadłości, które mógł pozostawić w spadku; według bulli papieża Hadriana IV, w której w 1155 r. zostały potwierdzone posiadłości biskupstwa wrocławskiego ${ }^{23}$, pewien comes Wlaz swego czasu podarował biskupstwu trzy wsie - można więc w tym imieniu Wlaz dostrzec właśnie Vlosta, ojca Piotra; o dziadku Piotra zaś - poza bullą z 1193 r. - nic więcej nie słyszymy. Z dokumentu dla klasztoru Najświętszej Maryi Panny we Wrocławiu, późniejszej fundacji świętego Wincentego, z 1139 lub $1149 \mathrm{r}^{24}$, znamy jednak pewną comitissa Vlostonissa, która mogła być matką komesa Piotra lub żoną Vlosta; nadała ona klasztorowi wieś - najwyraźniej należącą do jej lub do rodzinnego majątku. To, że według tego samego dokumentu komes Piotr jako fundator klasztoru przekazuje mu ze swej strony kilka wsi (comes Petrus fundator ecclesie Virbeno, Odram, Crescenicam dedit et Olauam), można również zinterpretować w ten sposób, że Piotr przekazał swoją własność. Jednak skoro - nadal według tego samego dokumentu - położona w bezpośredniej bliskości klasztoru na wrocławskim Ołbinie tawerna jak też tamtejszy targ zostały w 1149 r. nadane klasztorowi przez księcia, a nie przez komesa Piotra, może to przemawiać za tym, że Piotr nie dysponował Ołbinem w rozumieniu dziedzicznych dóbr alodialnych, lecz posiadał je raczej dzięki nadaniu książęcemu, przy którym książę zachował dla siebie jako prerogatywy ważne regalia: targ i gospodę ${ }^{25}$.

Również inne wskazówki świadczą o tym, że komes Piotr nie posiadał wszystkich swych dóbr, które później nadał kościołowi, jako dziedziczną własność rodzinną. I tak z wystawionego między 1180 i 1201 r. dokumentu księcia Bolesława Wysokiego, w którym opisano uposażenie klasztoru Najświętszej Maryi Panny na wrocławskim Piasku ${ }^{26}$, dowiadujemy się, że ową wieś Tinz, którą Piotr nadał klasztorowi, najpierw kupił od pewnego Żyda (villam Tinech emit comes Petrus a Iudeis et dedit sancte Marie). Podobne informacje czerpiemy z opowiadania kronikarza z Zwiefalten, któ-

\footnotetext{
22 M. Cetwiński, Piotr Wtostowic, s. 429-431.

23 SUB nr 28.

24 SUB nr 19.

25 Por. S. Arnold, Możnowładztwo polskie w XI i XII wieku i jego podstawy gospodarczo-społeczne, Przegl. Hist. 25 (1925), s. 1-32, cytowane według przedruku w: tenże, Z dziejów średniowiecza. Wybór pism, Warszawa 1968, s. 149-197, tu s. 167-178.

26 SUB nr 58.
} 
ry jeszcze za życia komesa Piotra opisywał, jak ten, aby lepiej móc uposażyć fundowane przez siebie klasztory, nabył od księcia Bolesława Krzywoustego w zamian za cenną relikwię z Rusi, mianowicie rękę męczennika Stefana, duże dobra ziemskie (fertilissimo predio nomine Rostkin plus quam 5 [quinqua] milia houbarum) ${ }^{27}$. Narracja z Zwiefalten nie mówi wcale o odziedziczonym majątku, którym dysponował Piotr, ale o bogactwach (diviciae) i środkach pieniężnych (pecunia, propria sumptūs). Skąd pochodzily te bogactwa, wzmiankuje Herbord, gdy donosi, że uprowadzony przez Piotra ruski książę Wołodar został przez niego puszczony wolno dopiero, gdy obiecał „oddać wszystko, co dzięki gorliwości i zdolnościom swych przodków zastał w skarbcach: złoto i srebro, wszystkie kosztowności w postaci naczyń, szat i różnych rodzajów dzieł sztuki, które przywieziono do Polski zaprzęgami konnymi i wielbłądami”28. To, że mistrz Wincenty w swej opowieści ${ }^{29}$ przemilczał to porwanie i zdobyte bogactwa, nie musi nic oznaczać. Moralizującemu krakowskiemu kronikarzowi chodzi w pierwszym rzędzie o wartości idealne, reprezentowane przez Piotra - czyli o jego rozum, odwagę, męskość. I jeśli według Wincentego do moralnej wielkości Piotra należy również to, że odrzucił on całe proponowane mu przez księcia za ten czyn wynagrodzenie, to jest to właśnie raczej dowód na to, że militarne i inne wyczyny drużynników na rzecz księcia na ogół były hojnie wynagradzane. Taka nagroda przekazywana była przede wszystkim w formie udziałów w zdobyczach, a raczej rzadziej w konkretnych nadaniach ziemskich. Wzmianka o tym, że bogactwo i stan posiadania komesa Piotra składały się w pierwszej linii z dóbr zdobytych przez niego samego, a nie odziedziczonych po przodkach, znajduje się też w Kronice Wielkopolskiej, która, jak wiemy, donosi o zrabowanym z Danii ogromnym skarbie. Dla wielkopolskiego kronikarza był to właśnie ów thezaurus regium, który w połączeniu z książęcymi nadaniami stanowił podstawę jego pozycji materialnej (cum quo [thezauro] multas possessiones pro se et suis liberis compararvit et nonullas hereditates ex largicione regis Boleslai et suorum filiorum successione sibi donatas fuerat in diversis provinciis regni Poloniae consecutus) $)^{30}$.

$\mathrm{Z}$ rozległych, prastarych posiadłości rodowych czy rodzinnych, którymi Piotr miał rzekomo - jak chce na przykład Stanisław Bieniek - dysponować we Wrocła-

\footnotetext{
27 Jak przyp. 7.

28 Jak przyp. 9; por. Heiligenleben zur deutsch-slawischen Geschichte. Adalbert von Prag und Otto von Bamberg, hrsg. v. J. Strzelczyk, L. Weinrich, Darmstadt 2005, s. 349.

29 Jak przyp. 10.

30 Jak przyp. 11.
} 
wiu i okolicach, na Ślęży, w Trzebnicy i jej pobliżu, jak też w okolicy Strzelna ${ }^{31}$, po weryfikacji źródeł nie zostaje zbyt wiele. Z pewnością obok ojca i matki jako fundatorzy dóbr kościelnych występują również brat Piotra Bogusław i jakiś dalszy krewny o imieniu Ceseborus, tak więc oni - i to znaczy cały ród lub cała rodzina komesa Piotra - na pewno władali ziemią i ludźmi. Nie można jednak udowodnić, że te posiadłości - jak sądzi część polskich badaczy - sięgają przedpiastowskich czasów plemiennych. O wiele bardziej analizowane źródła zdają się wskazywać na to, że większa część materialnych dóbr komesa Piotra wyrosła z jego udziału we władzy książęcej. Przyjrzyjmy się więc jeszcze raz źródłom szczególnie pod tym kątem, a równocześnie trzeciemu wyznacznikowi szlachty wskazanemu wcześniej.

\section{O udziale komesa Piotra we władzy}

Już sam tytuł comes, z którym Piotr występuje od samego początku, ukazuje go jako pełniącego urzędy książęce, drużynnika, dosłownie: towarzysza księcia. Już Gall Anonim na początku XII w. używał w swej kronice Cronicae et gesta ducum sive principum Poloniae tego pojęcia nie jako określenia wysokiego osobistego statusu, ale jako określenia funkcji urzędowej. I tak opisywał Sieciecha jako comes palatinus tylko tak długo, jak długo ten ów urząd piastował. Po jego obaleniu urząd comes palatinus pozostawał, według Galla Anonima, przez pewien czas nieobsadzony. Również inne osoby pełniące wysoką funkcję w książęcej administracji, jak comes Wratislavienis Magnus, były określane przez Galla jako comites. Nie w każdym przypadku chodziło o to, co zaznacza kronikarz, że były to koniecznie osoby szlachetnego pochodzenia (nobiles) ${ }^{32}$. Jak podsumował Modzelewski, słowo 'comes' u Galla określało „grupę osób, która na ówczesnej płaszczyźnie hierarchii państwowej sprawowała najwyższe urzędy", a w żadnym razie nie wszystkich możnych. Na określenie tych ostatnich, to znaczy jako ogólne określenie możnych czy szlachty, Gall stosował terminy 'proceres' i 'principes', które przeciwstawiał prostemu ludowi (populus). W tym przeciwstawieniu Modzelewski słusznie widział opozycję rządzących i rządzonych. Do tych pierwszych należeli wszyscy możni, principes lub proceres, optimates, nobiles; książę wysłuchiwał ich zdania w takiej czy innej formie i mieli oni udział w decyzjach politycznych. Jednak tylko komesi sprawowali najwyższy urząd i wybijali się

\footnotetext{
31 Por. S. Bieniek, Piotr Wtostowic, s. 31-38.

32 Galli anonymi cronicae et gesta ducum sive principum Polonorum, wyd. K. Maleczyński, MPH s.n., t. II, Kraków 1952, s. 69-71, 76-84.
} 
z szeregów principes - nie każdy princeps był więc też comes, ale każdy comes był princeps $^{33}$.

Nasz komes Piotr wybił się więc z kręgu principes i nobiles, do którego w tym rozumieniu zaliczały go, stosując to właśnie określenie, Annales Magdeburgenses oraz kronika z Zwiefalten, przez swój urząd, swoje zasługi dla księcia, to znaczy swój szczególny udział w książęcej władzy. Również u Herborda pod względem terminologicznym mowa jest wyraźnie o udziale Piotra we władzy, kiedy bamberski mnich nazywa go dosłownie milicie ductor i praefectus a duce super viros bellatores i dodaje, że chodzi tu o „człowieka jasnego umysłu i dzielnego w swej sile (co do którego nie wiadomo, czy miał większe znaczenie w boju, czy w doradzaniu)" (virum acris ingenii et fortem robore, de quo dubium, utrum in armis an in consiliis maior fuerit $)^{34}$. Także mistrz Wincenty portretuje Piotra jako nadzwyczaj mądrego i dzielnego męża, który odgrywał wiodącą rolę jako doradca księcia, a nawet przez pewien czas był najbliższy księciu spośród wszystkich możnych państwa (principi dignitate proximus) ${ }^{35}$. Jak ta bliskość i wierność wyrażała się w konkretnych działaniach, obrazuje wspomniana już opowieść o uprowadzeniu ruskiego księcia Wołodara. Jak wiemy ze źródeł dwunastowiecznych, a więc od kontynuatora Ortlieba, Herborda i Wincentego, Bolesław III, gdy po śmierci swej ruskiej żony Zbysławy w 1113 r. odnowił konflikt z Rusią Kijowską, naradzał się ze swymi urzędnikami i możnymi, jak w tej sprawie najlepiej postąpić. Komes Piotr jako jeden z kompetentnych doradców księcia ostrzegał przed walką na wielu frontach, ponieważ obawiał się, że Rusini ściągną do walki przeciw Polsce nie tylko Połowców, lecz także Pomorzan i Prusów. „Dlatego wymyśliłem plan - takie słowa przy tej okazji włożył Herbord w usta Piotrowi - aby Ruś pokonać lepiej przy pomocy podstępu" ${ }^{36}$. Książę i pozostali możni zaakceptowali plan Piotra, który udał się z trzydziestoma wiernymi stronnikami do księcia Przemyśla Wołodara, podał się tam za zbiega politycznego, zyskał zaufanie ruskiego księcia i nadużywając tego zaufania, a nawet łamiąc przysięgę - porwał go do Polski, aby za jego uwolnienie wymusić zawarcie pokoju i wielki łup. O tym ostatnim już przecież słyszeliśmy.

33 K. Modzelewski, Comites, Principes, Nobiles: The Structure of the ruling class as reflected in the terminology used by Gallus Anonymus, [w: The Polish nobility in the middle Ages: Anthologies, ed. A. Gąsiorowski, Wrocław 1984, s. 177-206, tu s. 188-192.

34 Jak przyp. 9; Heiligenleben zur deutsch-slawischen Geschichte, s. 347.

35 Magistri Vincentii dicti Kadtubek Chronica, s. 108.

36 Jak przyp. 9; Heiligenleben zur deutsch-slawischen Geschichte, s. 347. 
Również dalszy polityczny los Piotra, o którym dowiadujemy się z ukończonej po 1200 r. Kroniki Kijowskiej ${ }^{37}$, a następnie z późniejszych polskich źródeł, począwszy od Kroniki Wielkopolskiej ${ }^{38}$, potwierdza jego znaczący udział w sprawowaniu władzy - nawet jeśli przy tej okazji jesteśmy informowani, że ta władza została mu siłą odebrana. Wraz ze śmiercią Bolesława III w 1138 r. weszła w życie szczególna regulacja następstwa tronu, która władzę nad państwem Piastów dzieliła pomiędzy czterech synów zmarłego księcia, przy czym najstarszemu, Władysławowi II, przypadła w udziale zwierzchność senioralna. Ten jednak już wkrótce - rzekomo nakłoniony przez swą bamberską żonę Agnieszkę, co do której polskie źródła są wrogo nastawione - nie zadowolił się senioratem i od wczesnych lat czterdziestych XII w. dążył do jedynowładztwa. W tym kontekście najwyraźniej obawiał się, że comes palatinus Petrus, którego pozostawił na jego urzędzie i który nadal umacniał swą pozycję we Wrocławiu, mógłby przejść na stronę młodszych braci lub wystąpić jako obrońca tego nowego porządku senioralnego. Pod koniec 1145 r. pozbył się go więc, oślepiając go i wypędzając. Jednak już wkrótce po tym, w 1146 r., senior sam został wypędzony przez swych młodszych braci i możnych, którzy najwyraźniej przestraszyli się losu komesa Piotra, seniorem zaś został kolejny wiekiem brat, Bolesław IV Kędzierzawy. Bolesław IV musiał pewnie szybko rehabilitować komesa Piotra, skoro występuje on w dokumencie wrocławskiego biskupa Waltera z przełomu 1149 i 1150 r. znów na eksponowanym stanowisku, to znaczy jako po księciu najwyższy rangą przedstawiciel władzy w państwie ${ }^{39}$. Szeroki, aktywny udział komesa Piotra w monarchicznym sprawowaniu władzy jest więc bezsporny.

\section{O kościelnej działalności komesa Piotra}

Piotrowe fundacje kościelne i klasztorne, ściśle związane z jego pozycją polityczną i majątkową, nie pozostawiają wątpliwości co do tej dziedziny jego działalności. Już źródła średniowieczne przypisywały Piotrowi ogromną działalność fundacyjną.

37 Polnoe sobranie ruskich letopisej, t. II, St. Petersburg 1843, s. 21, ad annum 6653 [1145]: „Vladislva ljadskij knjaz, em muža svoego Petrka, i slepi, a jazyka emu ureza i dom ego rozgrabi, tokmo s ženoju i detmi vygna iz zemli svoeja”.

38 Chronica Polonorum (= Chronicon Polono-Silesiacum), wyd. L. Ćwikliński, [w:] MPH, t. 3, Lwów 1878, s. 578-656, tu s. 628-632; Chronica principum Poloniae, wyd. Z. Węclewski, [w:] MPH, t. 3, Lwów 1878, s. 423-578, tu s. 476-478; szczegółowo, z wieloma późniejszymi amplifikacjami, powstała w XIV w. Cronica Petri comitis Poloniae, wyd. M. Plezia, MPH s.n., t. III, Kraków 1951.

39 SUB nr 23. 
Kontynuator Ortlieba w połowie XII w. mówił o ponad 70 kościołach i klasztorach, które Piotr ufundował i bogato wyposażył (Inter alias enim [...] 70 [septuaginta] vel eo amplius decreverunt eum fabricare de propriis sumptibus aecclesias, inter quas nonulla monachorum decernunt eum edificare cenobia), rzekomo w ramach pokuty za swoje zbrodnie - m.in. związane z krzywoprzysięstwem i porwaniem księcia Wołodara - na rozkaz papieża lub polskich biskupów ${ }^{40}$. Podobną liczbę - zazwyczaj 77 - wymieniają również polskie kroniki z XIII-XVI w. ${ }^{41}$, przy czym Kronika Wielkopolska wylicza siedem fundacji klasztornych również z nazwy: klasztor Najświętszej Maryi Panny kanoników regularnych na wrocławskim Piasku, klasztor św. Wincentego na Ołbinie we Wrocławiu, po jednym opactwie w Czerwińsku i Sulejowie, klasztor w Strzelnie, prepozyturę św. Wawrzyńca koło Kalisza i kolejną w Mstowie ${ }^{42}$. Jan Długosz w swych Annales seu Chronicae i w Liber beneficiorum potrafil przytoczyć z nazwy łącznie 45 fundacji klasztornych i kościelnych, mających mieć związek $\mathrm{z}$ działalnością fundacyjną Piotra ${ }^{43}$. Wspólna wszystkim tym danym - bez wątpienia nacechowanym zarówno topiką symbolicznej lub świętej liczby, jak i późniejszymi amplifikacjami i legendami - jest pamięć o najwyraźniej niezwykłej działalności fundacyjnej wrocławskiego komesa.

Od XIX w. nauka wciąż na nowo próbuje dokładniej określić rozmiar tej działalności fundacyjnej, jednak dotąd nie uzgodniono jednego wspólnego stanowiska co do tego, które klasztory i kościoły rzeczywiście mogą być dziełem fundacyjnym komesa Piotra ${ }^{44}$. Rozpiętość wynosi tu od ośmiu do 70 fundacji - przy czym każdorazowo mamy do czynienia z inną definicją pojęcia „fundacja”. Źródła dwunastowieczne określają Piotra oczywiście tylko w wypadku dwóch obiektów kościelnych dosłownie jako fundatora, mianowicie w odniesieniu do kaplicy na wrocławskim Ołbinie i benedyktyńskiego klasztoru Najświętszej Maryi Panny, późniejszej fundacji św. Wincentego, której początki nauka sytuuje w drugiej połowie lat

\footnotetext{
40 Ortliebi de fundatione monasterii zwivildensis, s. 91.

41 Zob. przyp. 38.

42 Chronica Poloniae Maioris, s. 50.

43 Ioannis Dlugossii Annales seu Cronicae incliti regni Poloniae, lib. V, wyd. Z. Budkowa et. al., Warszawa 1973, s. 25; Ioannis Dlugossii Liber beneficiorum Dioecesis Cracoviensis, t. III, wyd. A. Przeździecki et. al., Kraków 1864, s. 163, 183.

44 Por. J. Dobosz, Monarcha i możni wobec Kościoła w Polsce do początku XIII wieku, Poznań 2002, s. 265-277; Z. Świechowski, Fundacje Piotra Wtostowica, [w:] Architektura Wrocławia, t. 3: Świątynia, red. J. Rozpędowski, Wrocław 1997, s. 9-21.
} 
dwudziestych XII w. i co do której również kronika z Zwiefalten wymienia komesa Piotra jako jej fundatora ${ }^{45}$.

Kwestią sporną pozostaje natomiast, czy powstanie drugiego wrocławskiego klasztoru maryjnego, kanoników regularnych na Piasku, również można bezpośrednio powiązać z komesem Piotrem. Niepewne wskazówki źródłowe i tradycja samego klasztoru sugerują, że pierwotnie - możliwe, że z inicjatywy ojca Piotra, Vlosta, ale być może też z jego własnej - mieścił się on najpierw na Ślęży i dopiero potem został przeniesiony na wrocławski Piasek ${ }^{46}$. Cytowany już dokument z przełomu 1149 i 1150 r. donosi, że biskup Walter na prośbę komesa Piotra przekazał dziesięcinę z dziewięciu wsi dla dwóch kościołów Najświętszej Maryi Panny, jednego na wrocławskim Piasku i jednego na Ślęży ${ }^{47}$. W końcu napis na tympanonie najstarszego kamiennego kościoła wymienia żonę i syna komesa Piotra jako fundatorów tej kościelnej budowli ${ }^{48}$, można więc uznać za bardzo prawdopodobne, że Piotr osobiście brał udział w zakładaniu i pierwszym uposażeniu tego klasztoru na Piasku, a możliwe, że też jego poprzednika na Ślęży.

Kwestią sporną pozostaje natomiast nadal to, czy komes Piotr może uchodzić również za fundatora klasztoru premonstratensów w Strzelnie ${ }^{49}$. Nowsze badania archeologiczne pokazały, że obydwa zachowane do dziś kościoły klasztorne - rotunda św. Prokopa i kościół Świętej Trójcy ze swymi słynnymi romańskimi kolumnami - najpewniej nie zostały wzniesione przed drugą połową XII w. ${ }^{50}$ Dlatego znak z jednej z kolumn w kościele Świętej Trójcy, interpretowany jako monogram komesa Piotra, nie może stanowić dowodu na to, że Piotr nakazał budowę kościo-

45 Ortliebi de fundatione monasterii zwivildensis, s. 91.

46 Por. A. Moepert, Peter Wlast und die Stiftung des Augustinerklosters auf dem Zobten, Breslau 1939 (Zur schlesischen Kirchengeschichte, Bd. 39.); W. Korta, Uposażenie klasztoru kanoników regularnych na górze Ślęży, Zapiski Historyczne 50 (1985), s. 51-67; M. Cetwiński, Chronica abbatum beatae Mariae virginis in arena o początkach klasztoru, [w:] Metamorfozy ślaskie. Studia źródłoznawcze i historiograficzne, red. tenże, Częstochowa 2002, s. 87-94.

47 Jak przyp. 39.

48 Napis brzmi: Has matri veniae tibi do Maria Mariae has offert aedes Swentislavs mea proles; por. K. Mączewska-Pilch, Tympanon fundacyjny z Ołbina na tle przedstawień o charakterze donacyjnym, Wrocław 1973.

49 Por. S. Bieniek, Uwagi nad powstaniem klasztoru $w$ Strzelnie i fundacjami Piotra Wtostowica $z$ około połowy XII wieku, Bydgoskie Towarzystwo Naukowe. Prace Wydziału Nauk Humanistycznych. Seria C: Prace komisji historii 2 (1964), s. 33-54; K. Hewner, Piotr Włostowic czy Piotr Wszeborowic? O fundatorze klasztoru norbertanek w Strzelnie, Nasza Przeszłość 94 (2000), s. 47-84.

50 Z. Świechowski, Katalog architektury romańskiej w Polsce, Warszawa 2009, s. 482, 489. 
$\mathrm{fa}^{51}$. O wiele bardziej prawdopodobne wydaje się, że wzniesienie kościoła zarządził jego wnuk o tym samym imieniu, przy czym nawiązywał on być może do fundacji swego dziadka, która w obrębie villa Strelno mogła jednak pierwotnie znajdować się w innym miejscu; w każdym razie nie odkryto dotąd w obecnym miejscu klasztoru żadnych archeologicznych czy architektonicznych śladów z pierwszej połowy XII w.

Bez względu na to, jak rozległa była działalność fundacyjna Piotra, czy obejmowała dwa, trzy czy siedem założeń klasztornych oraz jaki wydaje się jej zakres i jakość - to jednak w sumie powinno się dać wywnioskować z przekazów, nawet jeśli są one w szczegółach niepewne - przewyższała ona najwyraźniej znacznie to, co inni możni tej epoki zrealizowali jako fundatorzy. Tę działalność fundatorską można za Haliną Manikowską chyba najpewniej zinterpretować jako model princepsa fundatora, co jakiś czas temu pełniej uzasadnił Roman Michałowski ${ }^{52}$. Zgodnie z nim założone i wyposażone przez Piotra kościoły i opactwa miały służyć nie tylko do zapewnienia duchowej ochrony, łaski i pamięci jemu samemu i jego rodzinie, ale te korzyści miały też stać się udziałem całej wspólnoty, żyjącej na zarządzanym czy władanym przez Piotra terytorium i w ten sposób oddanej pod opiekę świętych patronów. W związku ze swoją szczególną pozycją, którą miał Piotr jako comes palatinus, mógł więc też dążyć do symbolicznego podniesienia i umocnienia wrocławskiego centrum swego obszaru władzy. W obraz ten wpisuje się również bardzo dobrze uroczyste przeniesienie relikwii św. Wincentego z Magdeburga do klasztoru na Ołbinie, najwyraźniej rodowego klasztoru Piotra, do którego mogło dojść latem 1145 r. dzięki wsparciu cesarza Konrada III. Zaangażowanie kościelne wrocławskiego komesa nie ograniczało się zresztą do założenia i uposażenia pojedynczych kościołów i klasztorów. Występował on raczej - jak na przykład w Rocznikach Magdeburskich - ogólnie jako „najczcigodniejszy zwolennik religii chrześcijańskiej” (christiane religionis sectator devotissimus), który, jak dalej przekonują Roczniki Magdeburskie, sprowadził relikwie św. Wincentego do Wrocławia nie z czysto politycznego wyrachowania, ale ad propagandum sub suo principatu catholicae religionis cultum ${ }^{53}$. Jako gorliwy obrońca

\footnotetext{
51 Jako monogram Piotra Włostowica interpretuje S. Bieniek, Uwagi, s. 39-40.

52 H. Manikowska, Princeps fundator w przedlokacyjnym Wrocławiu. Od Piotra Włostowica do Henryka Brodatego, [w: ] Fundacje i fundatorzy w średniowieczu i epoce nowożytnej, red. E. Opaliński, T. Wiślicz, Warszawa 2000, s. 37-57; R. Michałowski, Princeps fundator. Studium z dziejów kultury politycznej $w$ Polsce X-XIII wieku, Warszawa 1993.

53

Jak przyp. 8 .
} 
wiary rzymsko-katolickiej Piotr występuje również w liście krakowskiego biskupa Mateusza, który w latach 1143-1145 informował opata cysterskiego i propagatora krucjat Bernarda z Clairvaux o możliwościach nawrócenia ortodoksyjnej Rusi i zapraszał go do odwiedzenia Polski. Pismo wymienia Piotra jako współnadawcę i określa go jako męża stale najbardziej oddanego służbie bożej, Kościołowi i wierze (vir utique circa dei cultum et ecclesiam religionemque devotissimus) ${ }^{54}$.

\section{Podsumowanie}

Podsumujmy na koniec obserwacje poczynione na przykładzie komesa Piotra w sprawie wymienionych na wstępie czterech wyznaczników szlacheckości wczesnego lub pełnego średniowiecza w piastowskiej Polsce. Najpierw stwierdzić oczywiście należy, że nawet w wypadku komesa Piotra, co do którego istnieje o wiele więcej źródeł niż do jakiegokolwiek innego polskiego możnego X-XII w., wiele spraw i tak pozostaje niejasnych. Sądzę jednak, że na podstawie dostępnych źródeł - które omówiłem tu jedynie pobieżnie - można poczynić pewne ustalenia.

1. Rodzinne czy rodowe koligacje komesa Piotra da się prześledzić najwyżej dla dwóch pokoleń wstecz, a więc mniej więcej do połowy XI w. Stąd jego przykład nie może być dowodem na nieprzerwaną ciągłość społeczno-politycznej warstwy wyższej okresu plemiennego i piastowskiej szlachty XII w., na genetyczny związek między nimi. Co się tyczy jego regionalnego zakorzenienia, jako obszar jego działania uchwytny jest wprawdzie jednoznacznie Wrocław i jego najbliższa okolica, jednak działalność polityczna i kościelna komesa Piotra w żadnym razie nie ograniczała się do Śląska, za to - również w jego rozumieniu - jest „ogólnopiastowska”; nic nie wskazuje na to, że wysoka pozycja Piotra wynikała z pochodzenia z rodu śląskich wodzów plemiennych ani też że postrzegał on sam siebie jako regionalnego księcia czy potomka regionalnej dynastii plemiennej.

2. Materialna podstawa jego działalności, jego majątek i stan posiadania nie wydają się pochodzić z odziedziczonych wielkich posiadłości ziemskich, których gromadzenie mieliby rozpocząć jego przodkowie, czy to w przedpiastowskiej epoce

\footnotetext{
54 SUB nr 11; ostatnio M. Dygo, Wokót listu biskupa krakowskiego Mateusza do Bernarda, opata z Clairvaux, [w:] Europa barbarica, Europa christiana. Studia mediaevalia Carolo Modzelewski dedicata, red. R. Michałowski, Warszawa 2008, s. 47-58; Z. Piłat, List biskupa Mateusza i Piotra do Bernharda z Clairvaux, [w:] Narrata de fontibus hausta. Studia nad problematyką kościelna, polityczną i archiwistyczna, red. A. Brańska, W. Matwiejczyk, Lublin 2010, s. 101-123.
} 
plemiennej, czy za czasów Mieszka I lub Bolesława Chrobrego. Źródła pokazują raczej, że posiadłości ziemskie komesa w czasie jego fundacji, a więc pewnie jeszcze w drugiej połowie jego życia, były umiarkowanej wielkości i że w celu dostatecznego uposażenia swych fundacji musiał on najpierw sam kupić część przekazanych im dóbr, wsi i ludzi. Decydującą podstawę swego majątku zdobył on więc raczej w formie łupów i wpływów z urzędów, które zyskał jako odpłatę za swe zasługi i wierność księciu.

3. W ten sposób udział w wykonywaniu władzy jawi się nie tylko jako warunek i podstawa pozycji rodzinnej i ekonomicznej komesa Piotra, ale też jako conditio sine qua non jego przynależności do wąskiego grona społecznie i politycznie uprzywilejowanych w ramach państwa, a więc jego rangi jako princeps czy nobilis $\mathrm{w}$ rozumieniu szlachty. Jawi się on właśnie przede wszystkim jako jeden z głównych piastujących urzędy książęce, który swą pozycję, swoje „szlachectwo” zawdzięczał najwyraźniej przede wszystkim służbie dla księcia.

4. Owa „szlachta” znajdowała wyraz również w szczególnym zaangażowaniu na rzecz Kościoła, którego najważniejszym elementem był rozległy program fundacyjny. Program ten umotywowany był wcale nie na końcu chęcią zyskania sławy w teraźniejszości i u potomnych oraz uznania za nobilis, a więc za osobę, która przez swe szczególne przymioty psychiczne, charakterologiczne, moralne i duchowe wybijała się ponad zwykłych ludzi. „Szlachetny” był bowiem, jak stwierdził Otto Gerhard Oexle ${ }^{55}$, szczególnie ten, „kto był tak nazywany przez swych współczesnych” i czyja „szlacheckość” była konstytuowana również przez pamięć, przez memorię.

Nadesłany: 25 VII 2020

Nadesłany po poprawkach recenzyjnych: 16 I 2021

Zaakceptowany: 18 I 2021

Prof. dr hab. Eduard Mühle

Historisches Seminar Westfälische Wilhelms-Universität

Domplatz 20-22

D-48143 Münster

muehleed@uni-muenster.de

55 O.G. Oexle, Aspekte der Geschichte, s. 23. 


\section{Resume}

The article explores whether one may speak of a Polish 'nobility' already for the $12^{\text {th }} \mathrm{c}$., provided individuals can be identified as 'nobles' by 1. a distinguished (clan or family) descent, 2. a considerable material wealth (earned by offices or derived from landownership), 3. a participation in royal/ducal power and 4. a disposition over Church offices and/or a special dedication to Church matters. The sources provide only for a few individuals of the 12 th c. some scant evidence allowing to reflect on the listed criteria. The most prominent figure in this respect is comes Piotr Wostowic ( + ca. 1153). The article shows how he fits into the four mentioned criteria of high Medieval Polish 'nobility' and to what extent we may speak of Piotr as a noble or representative of an early Piast nobility living during the first half of the $12^{\text {th }} \mathrm{c}$.

Ttumaczenie: Ewa Dratwa 